\title{
Agricultural Irrigated Land-Use Inventory for Osceola County, Florida, October 2013-April 2014
}

\author{
By Richard L. Marella and Joann F. Dixon
}

\begin{abstract}
A detailed inventory of irrigated crop acreage is not available at the level of resolution needed to increase the accuracy of current water-use estimates or to project future water demands in many Florida counties. This report provides a detailed digital map and summary of irrigated areas within Osceola County for the agricultural growing period October 2013-April 2014. The irrigated areas were first delineated using land-use data and satellite imagery and then field verified between February and April 2014. Selected attribute data were collected for the irrigated areas, including crop type, primary water source, and type of irrigation system. Results indicate that an estimated 27,450 acres were irrigated during the study period. This includes 4,370 acres of vegetables, 10,970 acres of orchard crops, 1,620 acres of field crops, and 10,490 acres of ornamentals and grasses. Specifically, irrigated acreage included citrus (10,860 acres), sod (5,640 acres), pasture (4,580 acres), and potatoes (3,320 acres). Overall, groundwater was used to irrigate 18,350 acres (67 percent of the total acreage), and surface water was used to irrigate the remaining 9,100 acres (33 percent). Microirrigation systems accounted for 45 percent of the total acreage irrigated, flood systems 30 percent, and sprinkler systems the remaining 25 percent. An accurate, detailed, spatially referenced, and field-verified inventory of irrigated crop acreage can be used to assist resource managers making current and future county-level water-use estimates in Osceola County.
\end{abstract}

\section{Introduction}

Agricultural irrigation water withdrawals generally are estimated in counties throughout Florida because most irrigators do not meter or report their usage, or the metered information obtained does not provide a cumulative total. The most common procedure used to estimate water withdrawals for agricultural irrigation is to multiply the reported or published acres of each crop irrigated by a crop-specific net irrigation requirement, also known as an application rate (Marella, 2014). Both the acres irrigated and the appropriate application rates are estimated by each water management district (WMD) for the counties within their boundaries. Many assumptions must be made to estimate water withdrawals using irrigated acreage data and application rates, and this report will focus on the irrigated acreage estimates made for Osceola County. Some of the problems associated with obtaining and using reported or published irrigated acreage data include:

- variations between agencies that compile such data on definitions, data-collection procedures, reporting levels, and differences in years published;

- inadequate documentation of accuracy and detail;

- missing data due to incomplete compilations, privacy restrictions, and a lack of differentiation between irrigated and non-irrigated crop tables;

- lack of information about irrigation method and water source;

- lack of spatial data describing the location of irrigated crop lands.

Accurate and detailed estimates of irrigated acreage are not available at the level needed to improve current water-use estimates or project future demands. An accurate, detailed, spatially referenced, and field-verified inventory of irrigated crop acreage can be used to assist resource managers making current and future county-level water-use estimates.

\section{Background}

In 1998, the five Florida WMDs each prepared a detailed regional water supply plan for areas or counties within their jurisdiction to determine whether existing sources of water were adequate for current and future water needs (Florida Department of Environmental Protection, 2013). Water needs include water for public supply, domestic/small public supply, commercial/ industrial/institutional self-supplied, power generation, agricultural irrigation, and recreational irrigation. The primary objective of these water supply plans was to project future water demands and develop alternative water supplies to help meet the projected demands.

In 2013, the Florida Legislature mandated that future water demand projections for the agricultural irrigation part of these water supply plans be provided by the Florida Department of Agriculture and Consumer Services for consideration by the WMDs (Corinne Hermle, Florida Department of Agriculture and Consumer Services, Office of Agricultural Water Policy, written commun., July 2014). These water supply plans typically project 20 years into the future and are updated by the 
WMDs on a 5-year cycle. Generally, all water supply plans are approved and adopted as policy guides by the governing board of each WMD.

Agricultural irrigation water withdrawals refer to water used for crop irrigation and for non-irrigation uses associated with agricultural and farming operations (Marella, 2014). Crop irrigation includes the application of water on lands to assist in cultivation of crops or to prevent crop damage caused by harsh weather. Non-irrigation uses include withdrawals for livestock watering, washing of dairy and farm equipment, augmenting ponds used for fish farming, and other farm uses (Marella, 2014).

\section{Purpose and Scope}

The purpose of this report is to present the results of a cooperative study between the U.S. Geological Survey (USGS) and the Florida Department of Agriculture and Consumer Services to provide a detailed digital map and summary of irrigated acreage within Osceola County (fig. 1) for the agricultural growing period October 2013-April 2014. The irrigated acreage was mapped and field verified, and selected attribute data were collected for those irrigated areas. Attribute data include crop type, irrigation system type, and primary water source. The field verification was conducted between February and April 2014, because most vegetable crops within the county are either being harvested, are currently growing, or have just been planted during this 3-month period. All other crops, such as orchards (citrus, blueberries, and peaches), ornamentals and nurseries, and field crops and grasses (sod, hay, seeds, rye, and pasture), were also field verified during the same 3-month period, even though most of these crops are grown year round. The study focused on locating, compiling, and verifying irrigated acreage by crop type and does not address any application rates or make any estimates of water use. The results of the study, published in this report, can be used to assist resource managers making current and future water-use estimates in Osceola County.

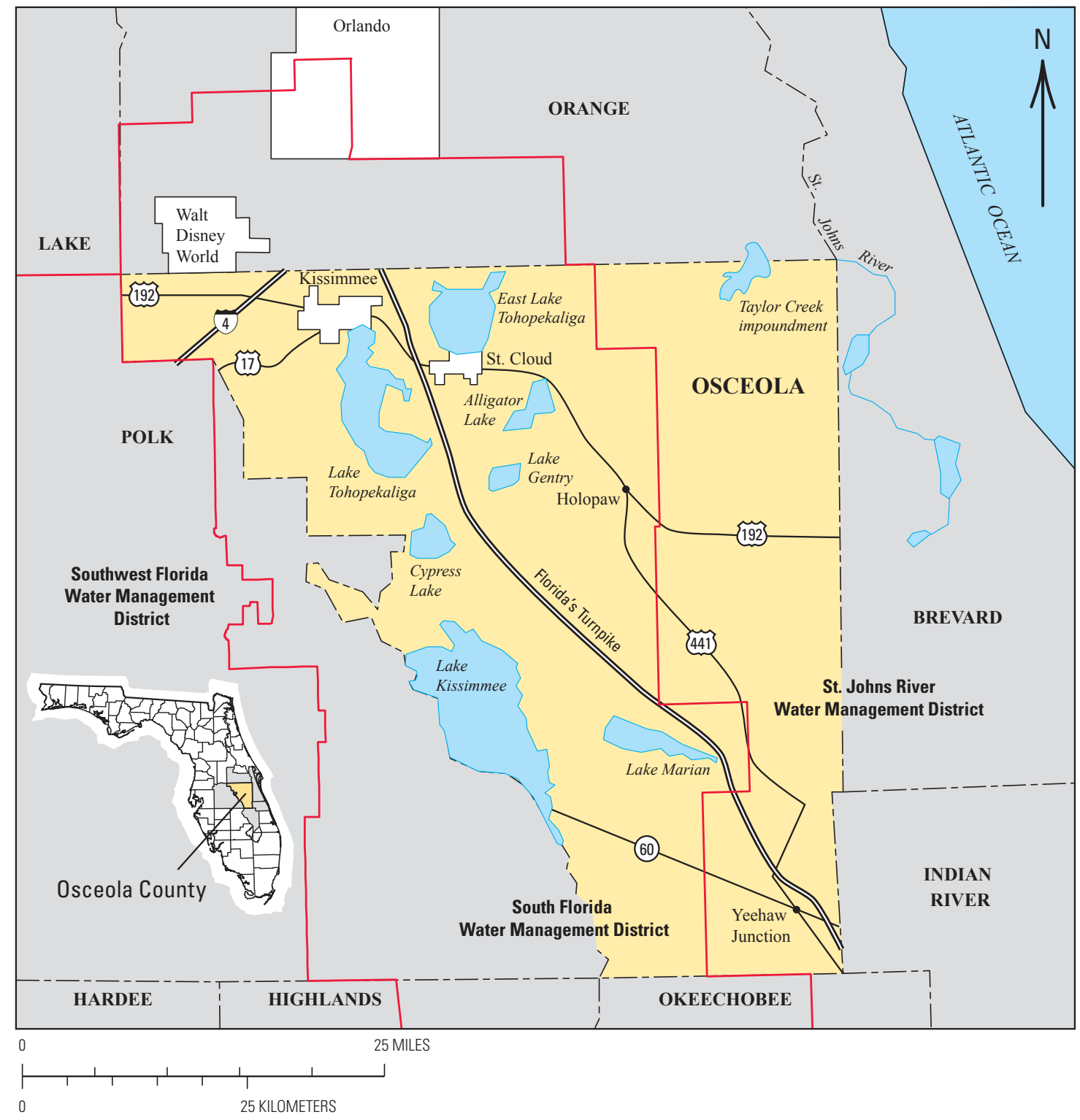

Figure 1. Map showing locations of Osceola County, Florida, and selected features and place names. 


\section{Osceola County Population, Land Use, and Water Withdrawals}

Osceola County is located in central Florida (fig. 1) and encompasses 1,350 square miles (Purdum, 1994). The northcentral and western parts of the county, near Kissimmee, are highly urbanized and adjacent to the Walt Disney World theme park complex (fig. 1). The population of Osceola County showed very little growth until the late 1970s when the theme park opened; the population has grown rapidly since the 1980s (fig. 2). The population of Osceola County increased more than tenfold from 26,000 in 1970, to 50,000 in 1980 (Dietrich, 1978), to 174,000 in 2000, and 270,700 in 2010 (U.S. Census Bureau, 2012). Most of this population and urban growth has occurred in the north-central and western parts of the county. The county population is projected to reach 450,000 by the year 2030 (Smith and Rayer, 2012).

The north-central part of the county, including the city of St. Cloud, Lake Tohopekaliga, and East Lake Tohopekaliga (fig. 1), is a mix of urban, rural, and agricultural land use, whereas the southern and eastern parts of the county, including Holopaw and Yeehaw Junction, are almost entirely rural with large areas of crop and cattle lands. According to the 2012 Census of Agriculture, Osceola County accounted for more pasture land than any other county in Florida, with more than 216,000 acres (U.S. Department of Agriculture, 2014).

The north-central and western parts of the county were once large citrus areas (in and around the city of Kissimmee and along Interstate 4), containing many small and mid-size groves; however, most of these groves have been sold and developed or abandoned over time. Citrus acreage in Osceola County totaled about 19,394 acres on 199 farms in 1982, but by 2012 the acreage had decreased to about 6,623 acres on 47 farms (U.S. Department of Agriculture, 1984, 2014). Most of the remaining citrus acreage is in the southern or eastern part

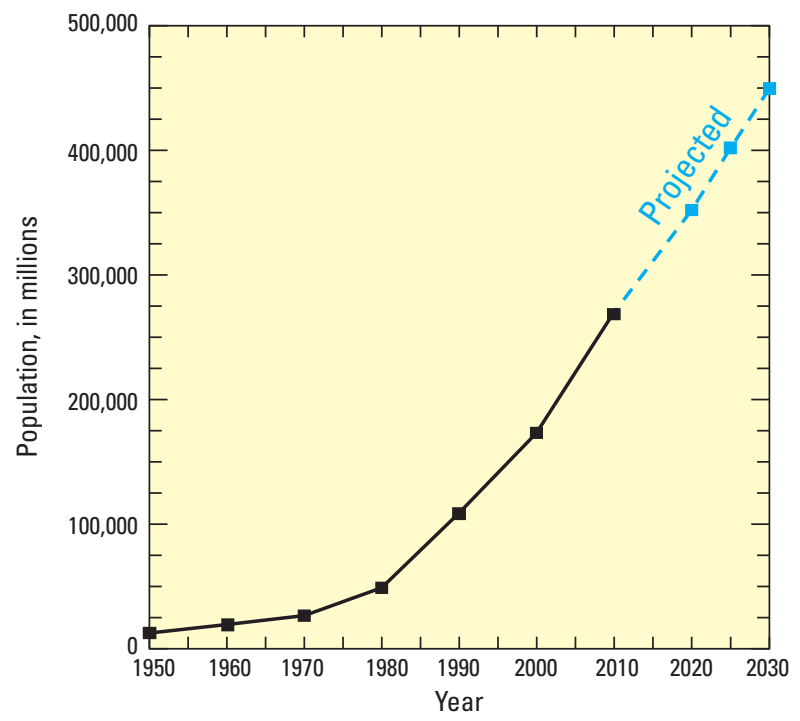

Figure 2. Historical and projected population of Osceola County, Florida, 1950-2030. of the county, with only small areas of citrus remaining in the north-central and western areas.

The agricultural community in Osceola County depends heavily on local water sources. In 2010, water withdrawals for agricultural irrigation totaled about 51 million gallons per day (Mgal/d) and accounted for 52 percent of the total withdrawals in the county (Marella, 2014). Water withdrawn for agricultural use in Osceola County is for crop production and cattle operations. Water withdrawn for public supply totaled $35 \mathrm{Mgal} / \mathrm{d}$ in 2010 , or 36 percent of the total withdrawals in the county (Marella, 2014).

In 2000, withdrawals for agricultural irrigation accounted for 73 percent of the total withdrawals, followed by public supply at 21 percent (Marella, 2004). Between 1975 and 2000, water withdrawals for agricultural irrigation in Osceola County increased steadily; however, withdrawals for agricultural irrigation decreased between 2000 and 2005 (Marella, 2009) and between 2005 and 2010 (fig. 3), returning to levels of those during the 1990s. Water withdrawals for public supply have increased steadily since 1985 (fig. 3). The decrease for agricultural irrigation withdrawals is due to losses of irrigated citrus and sod acreage, primarily between 2000 and 2010, whereas the increase in public supply withdrawals is due to a large increase in population, primarily between 1995 and 2010 (fig. 2).

Water withdrawals in 2010 in Osceola County totaled $98 \mathrm{Mgal} / \mathrm{d}$ (Marella, 2014). About 93 percent of the total water withdrawn in Osceola County in 2010 was obtained from the Floridan aquifer system, whereas the remaining water withdrawn was obtained from shallow aquifers, local canals, or lakes (Marella, 2014). Groundwater is the primary source of water in Osceola County because of the high quality and ready availability of the resource throughout the county (Schiner, 1993). The quality and availability of fresh groundwater will remain vital to the residents, visitors, and the agricultural community in Osceola County in the future.

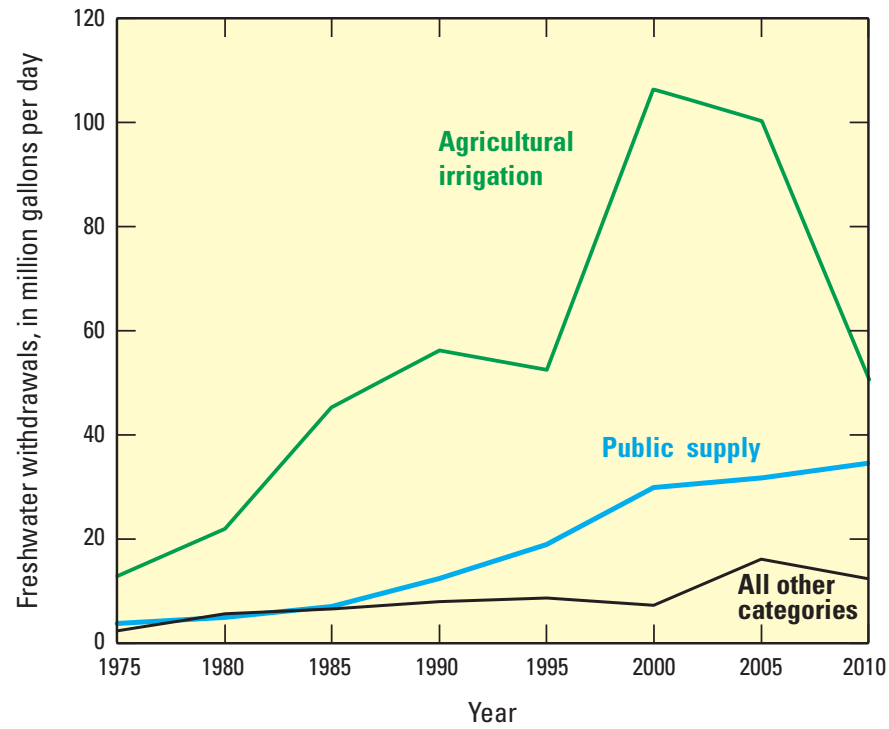

Figure 3. Historical water withdrawals in Osceola County, Florida, 1975-2010. 


\section{Map Development and Data Sources}

A preliminary map showing acreage by crop type was developed using land-use data collected for 2008-09. The preliminary map was revised using more recent orthoimages from 2011 to produce an adjusted map that was to be used for field verification. Once all of the field verification was completed and changes were made on the adjusted map and corresponding shape files, a final field-verified map was produced.

The preliminary map was developed from data obtained from the St. Johns River WMD and the South Florida WMD (fig. 1). The St. Johns River WMD data were from a land-use inventory completed by the WMD in 2009 (St. Johns River Water Management District, 2011a). The WMD used the Florida Land Use and Cover Classification System (FLUCCS) for 2006, and the data were field checked in 2007-08 by the district. The South Florida WMD data were from a land-use inventory completed by the WMD in 2008-09 (South Florida Water Management District, 2011). The FLUCCS was used, but the data were only spot checked by the district. These two datasets were merged to create the preliminary map.

Orthoimages were used to revise the preliminary map produced by the WMDs, and an adjusted map was created. Orthoimages were obtained from the USGS Earth Resources Observation and Science (EROS) Center and represent the images taken primarily during January of 2011 (Osceola_2011 ortho, produced by Surdex Corporation for the Osceola County Property Appraiser's Office). In areas where the land-use type or field shape differed, the preliminary map was adjusted to match the orthoimages. In many cases it was difficult to differentiate between improved and unimproved pasture in the orthoimages because of the time of year the images were taken (in most cases pasture grass is dormant in this part of Florida during January). It was also difficult to differentiate between irrigation or drainage ditches visibly seen in the fields. Many of these differences were resolved with input from the County Extension Office staff or with the use of images viewed using Google Earth. Google Earth images accessed during digitizing in 2013 represented images from January and February of 2011 with some images from periods in early 2013.

\section{Field Verification and Limitations}

The irrigated areas on the adjusted map were then ready to be field verified. The county was divided into two major areas for field verification on the basis of the predominant crop type: (1) the eastern, central, and southern areas of the county, which include nearly all of the vegetable crop and grass lands and (2) the north-central and western areas of the county, which include a large number of citrus groves (Appendix 1). Several trips were made to these two areas of the county between February and April 2014 to verify the planted and irrigated fields against the adjusted map.

The County Extension Office staff indicated that the period February-April would provide the best opportunity to verify vegetable crop production because most vegetable crops grown during the 8-month period October through May would be in one of three stages - harvesting, growing, or planting — during February-April. Vegetables grown in the county generally are harvested during January through June from plantings as early as October or as late as April. Most of the remaining crops throughout eastern, central, and southern Osceola County are grown year round and include orchard crops (blueberries, citrus, and peaches), ornamentals and nurseries, and field crops and grasses (sod, hay, seeds, rye, and pasture).

Field verification of the eastern, central, and southern areas of the county was less difficult than other areas, because access to most fields or groves was obtained through the County Extension Office. Field or grove layout was compared to the digitized areas shown on the adjusted map, and changes were made on the working copy. Specific attributes were recorded for each field including crop type, irrigation system (micro, flood, and sprinkler), and water source (ground or surface). Conversations with individual managers, farmers, or growers while visiting their fields also helped confirm or revise the field layout shown on the adjusted map as well as verify the attribute information collected.

For the many citrus groves in the north-central and western areas of the county, field verification was more challenging. Without direct access to most of the groves, it was difficult to determine from the roadside if the grove was active or abandoned. In general, a grove was categorized as abandoned if maintenance of the grove was not evident, trees were dead or barren, cows were present grazing among the trees, or a "for sale" sign was posted. Unless a grove was identified or labeled as abandoned, it was assumed active if an irrigation system was present. In many cases it was difficult to determine if some of the groves that did not appear to be abandoned were still in production.

With assistance from the U.S. Department of Agriculture (USDA) Office in Osceola County, most of the citrus groves in the north-central and western parts of the county (primarily around the urban areas of Kissimmee, St. Cloud, and along Interstate 4) were observed from the roadside and noted between February and April 2014. In addition, Osceola County staff went into certain areas in the north-central and western parts of the county to verify the condition or status of some specific groves. With the help of the County Extension Office and the USDA, the status of many, but not all, of the active or inactive groves was identified.

For the purpose of this inventory, it was assumed that if an irrigation system was present, the system would be in use for the current crop at some time during the growing period. This assumption was made because in only a small percentage of the many fields or groves that were visited between February and April 2014 an irrigation system was observed operating during the visit. Therefore, the irrigation totals presented in this report may be high, especially for citrus crops and pasture land, because inactive groves or pasture would be counted as irrigated only because the use of irrigation during that specific growing season could not be verified. In addition, a large portion of the irrigated pasture acreage located in eastern Osceola County is irrigated through gravity feed ditches filled from water obtained from free flowing wells. In most cases, these wells are opened periodically throughout the year or in some cases not opened at all. For the purpose of this inventory, most of the pasture land with this irrigation potential is included as irrigated within these results.

Upon completion of all of the field verification, a draft verified map was completed. This draft verified map was then reviewed by the County Extension Office and the USDA. Some issues were resolved and changes were made as a result, and a final verified map was produced (Appendix 1). 


\section{Results}

The results of data compilation and field verification (Appendix 1) indicate that during the growing season October 2013-April 2014, an estimated 27,450 acres were irrigated in Osceola County. This includes 4,370 acres of vegetable crops, 10,970 acres of orchards, 1,620 acres of field crops, and 10,490 acres of ornamentals and grasses (fig. 4). Row crop totals include about 30 acres of various irrigated vegetable crops that could not visually be verified between February and April 2014. Specific irrigated crops include citrus (10,860 acres), sod (5,640 acres), pasture (4,580 acres), and potatoes (3,320 acres) (table 1). The part of Osceola County in the South Florida WMD (fig. 1) accounted for 72 percent (19,830 acres) of the total irrigated acres in the county, and the part in the St. Johns River WMD (fig. 1) accounted for 28 percent (7,620 acres) (fig. 4). Overall, groundwater was used to irrigate 18,350 acres (67 percent of the total acreage), whereas surface water was used to irrigate the remaining 9,100 acres (33 percent). In addition, microirrigation systems accounted for 12,370 acres irrigated or 45 percent, flood systems accounted for 8,180 acres or 30 percent, and sprinkler systems accounted for the remaining 6,900 acres or 25 percent of the total acres irrigated during this 2013-14 growing season (table 1).
It is difficult to compare the field-verified results compiled in this study to results published by the USDA because methods differ substantially as do the reported years. Nevertheless, the total estimate of irrigated land compiled from this study (conducted in 2013-14) is about 6 percent less than the most recent estimates for Osceola County by the USDA (published with 2012 data) (fig. 5). The most recent Census of Agriculture estimates 29,153 total acres irrigated in Osceola County for 2012 (U.S. Department of Agriculture, 2014) compared to the current study results of 27,450 acres for 2013-14 (table 1). However, much of the detailed acreage data for specific crops within the 2012 Census of Agriculture report for Osceola County were either not available because of privacy issues or were not differentiated between irrigated and non-irrigated acreage (table 1).

According to the Census of Agriculture (U.S. Department of Agriculture, 1984, 1989, 1994, 1999, 2004, 2009, 2014), citrus and sod accounted for the majority acreage in Osceola County during the past 30 years (table 1). The acreage totals presented by the Census of Agriculture (for these seven Census of Agriculture publications) for these two crops do not differentiate between irrigated and non-irrigated. Total citrus acreage reported by the Census of Agriculture for 2012 was 6,623 acres, which is substantially different ( 39 percent lower) from the Osceola County

Figure 4. Irrigated acreage by crop type for Osceola County, Florida, and by Water Management District, October 2013-April 2014.

27,450 total acres

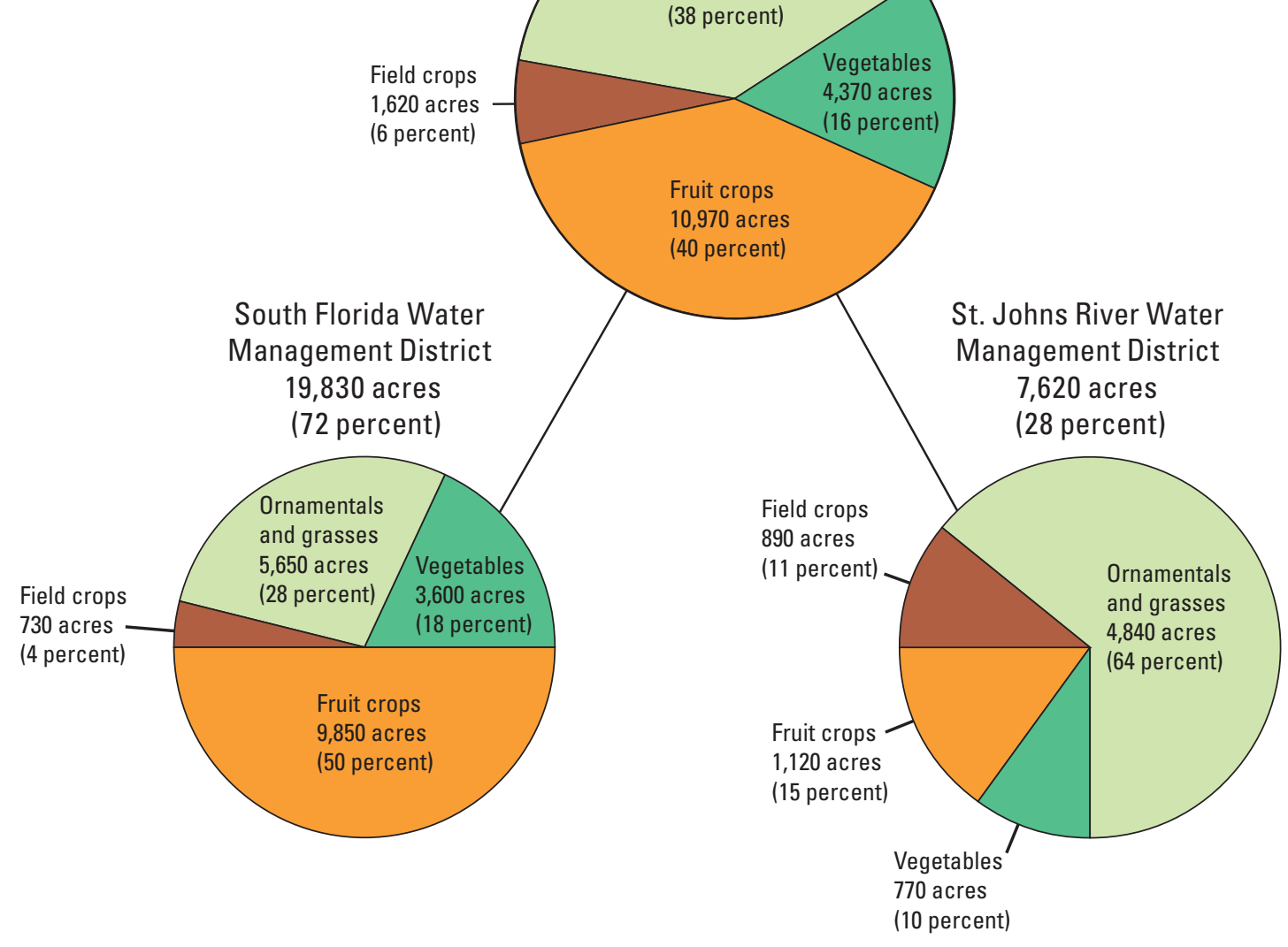


Table 1. Reported and inventoried crop and irrigated acreage in Osceola County, Florida, 1982-2014.

[Data were compiled by the U.S. Geological Survey (USGS), Caribbean-Florida Water Science Center, Orlando. D, values were not provided in the U.S. Department of Agriculture (USDA) published tables due to privacy issues; N/A, data not available; USDA acreage values (in italics) for citrus and sod represent total acreage because the USDA tables do not differ between irrigated and non-irrigated; all other USDA values reflect what was reported as irrigated. Microirrigation includes drip, spray, jet, and bubbler systems; Sprinkler irrigation includes portable and traveling guns, solid or permanent overhead fixtures, center pivots, and periodic moving systems; Flood irrigation (including seepage systems) includes open-field ditch (furrows), semi-closed conveyance, sub-surface conduit, crown flood, and continuous flood (Izuno and Haman, 1987; Marella, 2014)]

\begin{tabular}{|c|c|c|c|c|c|c|c|c|c|c|c|}
\hline \multirow[t]{2}{*}{ Crop type } & \multicolumn{7}{|c|}{ From U.S. Department of Agriculture, Census of Agriculture ${ }^{1}$} & \multicolumn{4}{|c|}{$\begin{array}{l}\text { U.S. Geological Survey } \\
\text { field-verified irrigated acres² }\end{array}$} \\
\hline & 1982 & 1987 & 1992 & 1997 & 2002 & 2007 & 2012 & 2013-14 & Micro & Sprinkler & Flood \\
\hline Vegetables & (D) & (D) & 9 & (D) & 978 & (D) & (D) & 4,370 & 1,050 & 780 & 2,540 \\
\hline Cabbage/Lettuce & & & & & & & & 0 & & & \\
\hline Cucumbers/Pickles & & & & & & & & 0 & & & \\
\hline Peppers (all) & & & & & & & & 180 & 180 & & \\
\hline Potatoes & & & & & & & & 3,320 & & 780 & 2,540 \\
\hline Tomatoes & & & & & & & & 0 & & & \\
\hline Sweet corn & & & & & & & & 0 & & & \\
\hline $\begin{array}{r}\text { Watermelons/ } \\
\text { Cantaloupes }\end{array}$ & & & & & & & & 630 & 630 & & \\
\hline $\begin{array}{r}\text { Vegetables } \\
\text { non-specific }\end{array}$ & & & & & & & & 240 & 240 & & \\
\hline $\begin{array}{c}\text { Fruit Crops } \\
\text { (Land in orchards) }\end{array}$ & N/A & $\mathrm{N} / \mathrm{A}$ & 12,217 & 14,982 & 9,533 & 7,862 & 6,210 & 10,970 & 10,800 & 170 & 0 \\
\hline Blueberries & & & & & & & & 40 & 40 & & \\
\hline Citrus & 19,394 & 15,398 & 14,559 & 17,195 & 11,051 & 8,561 & 6,623 & 10,860 & 10,690 & 170 & \\
\hline Grapes & & & & & & & & 0 & & & \\
\hline Peaches & & & & & & & & 70 & 70 & & \\
\hline Strawberries & & & & & & & & 0 & & & \\
\hline $\begin{array}{r}\begin{array}{r}\text { Fruit Crops } \\
\text { non-specific }^{4}\end{array} \\
\end{array}$ & & & & & & & & 0 & & & \\
\hline Field Crops & $\mathrm{N} / \mathrm{A}$ & $\mathrm{N} / \mathrm{A}$ & $\mathrm{N} / \mathrm{A}$ & $\mathrm{N} / \mathrm{A}$ & $\mathrm{N} / \mathrm{A}$ & $\mathrm{N} / \mathrm{A}$ & N/A & 1,620 & 290 & 1,330 & 0 \\
\hline Cotton & & & & & & & & 0 & & & \\
\hline Field corn & & & & & & & & 290 & 290 & & \\
\hline Peanuts & & & & & & & & 0 & & & \\
\hline Potatoes & & & & & & & & 0 & & & \\
\hline Rice & & & & & & & & 0 & & & \\
\hline Soybeans & & & & & & & & 0 & & & \\
\hline Sugarcane & & & & & & & & 0 & & & \\
\hline Tobacco & & & & & & & & 0 & & & \\
\hline Wheat & & & & & & & & 0 & & & \\
\hline $\begin{array}{r}\text { Field Crops } \\
\text { non-specific }{ }^{5} \\
\end{array}$ & & & & & & & & 1,330 & & 1,330 & \\
\hline Ornamentals/Grasses & N/A & N/A & N/A & N/A & N/A & N/A & N/A & 10,490 & 230 & 4,620 & 5,640 \\
\hline Field grown & & & & & & & & 0 & & & \\
\hline Greenhouse grown & & & & & & & & 0 & & & \\
\hline Container grown & & & & & & & & 270 & 230 & 40 & \\
\hline Pasture (improved) & & & & & & & & 4,580 & & 30 & 4,550 \\
\hline Sod & 1,669 & 6,173 & 3,499 & 8,584 & 8,484 & 14,250 & 6,933 & 5,640 & & 4,550 & 1,090 \\
\hline Irrigated land & 26,742 & 25,868 & 14,474 & 58,024 & 18,651 & 31,420 & 29,153 & 27,450 & 12,370 & 6,900 & 8,180 \\
\hline Number of farms & 141 & 178 & 174 & 197 & 140 & 98 & 62 & Percent & 45 & 25 & 30 \\
\hline Harvested cropland $^{6}$ & 35,011 & 32,501 & 26,074 & 30,345 & 27,448 & 29,901 & 22,130 & & & & \\
\hline Number of farms & 281 & 311 & 287 & 269 & 228 & 152 & 126 & & & & \\
\hline Total cropland $^{6}$ & 65,295 & 66,965 & 63,060 & 50,505 & 76,148 & 44,457 & 29,700 & & & & \\
\hline Number of farms & 360 & 390 & 287 & 355 & 296 & 185 & 146 & & & & \\
\hline
\end{tabular}

${ }^{1}$ Data for 1982, 1987, 1992, 1997, 2002, 2007, and 2012 were obtained from the USDA, Census of Agriculture (USDA, 1984, 1989, 1994, 1999, 2004, 2009, 2014).

${ }^{2}$ The acres reported by the USGS for the 2013-14 growing season include the period October 1, 2013, to April 30, 2014. Values shown in this table may differ from those presented in Appendix 1 due to rounding.

${ }^{3}$ Acreage includes beans (lima, pole, and snap), broccoli, carrots, cauliflower, celery, collards, eggplant, garlic, herbs, kale, mustard greens, okra, onions, parsley, peas (black-eyed, crowder, green, and southern), pumpkins, spinach, squash, turnip greens, radishes, and watercress.

${ }^{4}$ Acreage includes apples, avocados, bananas, guavas, mangoes, papayas, passion fruit, pears, pecans, persimmons, plums, and other non-citrus fruit.

${ }^{5}$ Acreage includes sorghum, wheat (for grain), oats (for grain), proso millet, rice, rye (for grain), dry southern peas (cowpeas), grass seeds, hay, forage, and silage crops.

${ }^{6}$ Excludes pasture. 
10,860 acres identified through the ground verification conducted between February and April 2014 as part of this study. A large part of this difference may be attributed to the inability to differentiate between active, inactive, and abandoned citrus groves during the field-verification process. Growers may have reported a grove as inactive or abandoned to the Census for 2012, but during field verification in 2014 the grove may have been visually identified as active and, therefore, included in the study results. Citrus acreage across central Florida has been declining since the late 1990s as a result of tree losses to hurricane damage, disease (such as canker and greening), and encroaching urbanization (U.S. Department of Agriculture, 2006; White and van Blokland, 2006).

Pasture irrigation is also substantial throughout Osceola County. Although the Census does not report the actual value for irrigated pasture, it does report that 13,276 acres of "pastureland and other land" were irrigated in 2012 (U.S. Department of Agriculture, 2014, table 10). The Census also reported that 15,877 acres of "harvested cropland" were irrigated (U.S. Department of Agriculture, 2014, table 10), thus totaling the 29,153 reported acres irrigated in 2012 (U.S. Department of Agriculture, 2014) for Osceola County (table 1). Harvested cropland includes vegetables, orchards, and ornamentals, and pastureland and other land includes pasture for grazing or hay production, sod, and seed production. Assuming that all of the reported sod acreage by the USDA for 2012 was irrigated (6,933 acres); the remaining 6,340 acres would represent the irrigated pasture totals as well as irrigated hay, rye and seed acreage. Subtracting the field-verified 1,330 acres of rye and seed (listed as Field Crops non-specific in table 1) from the 6,340 remaining acres, irrigated pasture acres from the Census would be estimated at 5,010 acres, or only 430 acres ( 8 percent) higher than the results of 4,580 acres for this study.

The results of this study provide a greater detail of the irrigated crops within Osceola County than do the published values. Information on crop type, irrigation system, and water source enable planners to better estimate current and future

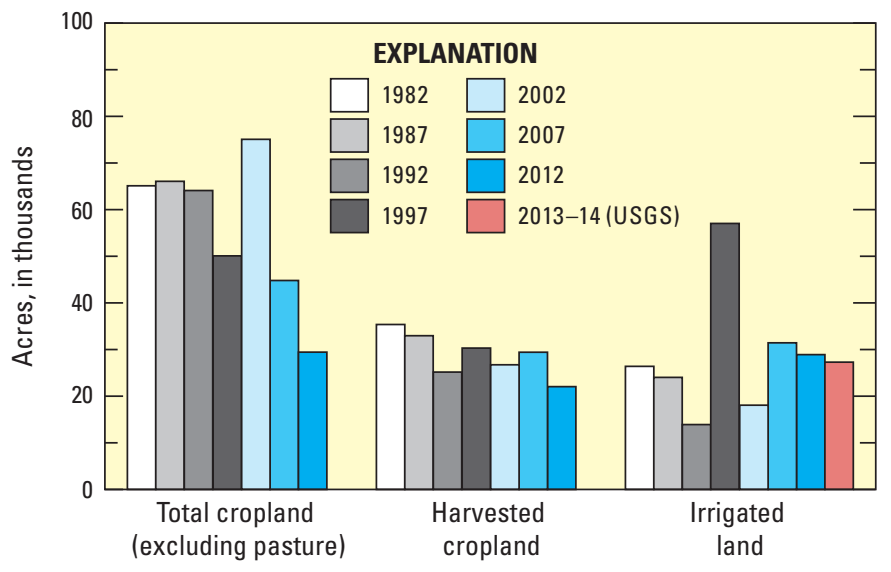

Figure 5. Reported and inventoried total cropland, harvested cropland, and irrigated land in Osceola County, Florida, 1982 through 2014. water needs. In addition, the spatial distribution of irrigated lands allows scientists to better assign withdrawal values geographically for ground and surface-water models and better identify water using activities at a local or regional level.

\section{Further Information}

Additional information on current and future water demands for agricultural irrigation in Osceola County can be obtained from the St. Johns River WMD (St. Johns River Water Management District, 2011b) and the South Florida WMD (South Florida Water Management District, 2009). The final field-verified map (Appendix 1) along with digital layers and attribute files described in this report are available for download from the USGS Web site http://fl.water.usgs.gov/infodata/ wateruse.html or by contacting the USGS Caribbean-Florida Water Science Center offices in Davie, Lutz, or Orlando, Florida, or Guaynabo, Puerto Rico.

\section{Acknowledgments}

The authors gratefully acknowledge the Florida Department of Agriculture and Consumer Services, Office of Agricultural Water Policy, for its participation and cooperation in this agricultural irrigation land use project for Osceola County including the following staff who provided program support or technical assistance from the Office of Water Policy in Tallahassee: L. Terry Pride, W. Ray Scott, Holly Edmonds, and Corinne Hermle. Appreciation is extended to James H. Fletcher, Osceola County Extension Director, Institute of Food and Agricultural Science (IFAS), University of Florida, and Chuck O'Rourke, District Conservationist, U.S Department of Agriculture (USDA), Natural Resources Conservation Service (NRCS), for providing assistance, expertise, and staff time needed to produce maps, update field information, and contact farmers. Special appreciation is extended to Valarie Anderson of the local NRCS office and J.J. White of Osceola County for the many hours spent driving through the urban and rural areas of Osceola County to help delineate or verify fields, groves, and pasture areas.

\section{Selected References}

Dietrich, T.S., 1978, The urbanization of Florida's populationAn historical perspective of county growth 1830-1970: Gainesville, Fla., University of Florida, College of Business Administration, Bureau of Economic and Business Research, $211 \mathrm{p}$.

Florida Department of Environmental Protection, 2013, Annual status report on regional water supply planning: Tallahassee, Fla., Office of Water Policy, 16 p., accessed December 1, 2014, at http://www.dep.state.fl.us/water/waterpolicy/ rwsp.htm.

Izuno, F.T., and Haman, D.Z., 1987, Basic irrigation terminology: Gainesville, Fla., University of Florida, Institute of Food and Agricultural Sciences, Agricultural Engineering Fact Sheet AE-66, 4 p. 
Marella, R.L., 2004, Water withdrawals, use, discharge, and trends in Florida, 2000: U.S. Geological Survey Scientific Investigations Report 2004-5151, 136 p.

Marella, R.L., 2009, Water withdrawals, use, and trends in Florida, 2005: U.S. Geological Survey, Scientific Investigations Report 2009-5125, 50 p.

Marella, R.L., 2014, Water withdrawals, use, and trends in Florida, 2010: U.S. Geological Survey, Scientific Investigations Report 2014-5088, 59 p.

Purdum, E.D., 1994, Florida county atlas and municipal fact book: Tallahassee, Fla., Florida State University, Institute of Science and Public Affairs, 146 p.

Schiner, G.R., 1993, Geohydrology of Osceola County, Florida: U.S. Geological Survey Water-Resources Investigations Report 92-4076, 68 p.

Smith, S.K., and Rayer, Stefan, 2012, Projections of Florida population by county 2011-2040-March 2012: Gainesville, Fla., University of Florida, Bureau of Economic and Business Research, Bulletin 162 (revised), 8 p.

South Florida Water Management District, 2009, Kissimmee Basin water supply plan, 2005-2006 update: West Palm Beach, Fla., South Florida Water Management District, 119 p.

South Florida Water Management District, 2011, SFWMD 2008-2009 Land cover and land use primary feature vlass (ver. 1.1): West Palm Beach, Fla., SFWMD IT-GIS, 1:12,000 scale, accessed September 14, 2011, at http://www.sfwmd.gov/gisapps/sfwmdxwebdc/ dataview.asp?query $=$ unq_id $=2184$.

St. Johns River Water Management District, 2011a, 2008-2009 Land cover and land use: Palatka, Fla., St. Johns River Water Management District, 1:12,000 scale, accessed November 11, 2011, at ftp://secure.sjrwmd.com/disk6b/lcover_luse/ lcover 2009/.

St. Johns River Water Management District, 2011b, 2010 Survey of estimated annual water use for the St. Johns River Water Management District: Palatka, Fla., St. Johns River Water Management District Technical Fact Sheet SJ2011-FS, $24 \mathrm{p}$.

U.S. Census Bureau, 2012, Statistical abstract of the United States-2012 (131st ed.): Washington D.C., U.S. Department of Commerce, Bureau of the Census, accessed December 1, 2014, at http://www.census.gov/compendia/statab/.
U.S. Department of Agriculture, 1984, 1982 Census of agriculture-Florida state and county data: Washington D.C., U.S. Department of Agriculture, National Agricultural Statistics Service, Geographic Area Series, part 9 [AC 07-A-9], v. 1, 439 p.

U.S. Department of Agriculture, 1989, 1987 Census of agriculture-Florida state and county data: Washington D.C., U.S. Department of Agriculture, National Agricultural Statistics Service, Geographic Area Series, part 9 [AC 07-A-9], v. 1, 445 p.

U.S. Department of Agriculture, 1994, 1992 Census of agriculture-Florida state and county data: Washington D.C., U.S. Department of Agriculture, National Agricultural Statistics Service, Geographic Area Series, part 9 [AC 07-A-9], v. 1,439 p.

U.S. Department of Agriculture, 1999, 1997 Census of agriculture - Florida state and county data: Washington D.C., U.S. Department of Agriculture, National Agricultural Statistics Service, Geographic Area Series, part 9 [AC 07-A-9], v. 1, 444 p.

U.S. Department of Agriculture, 2004, 2002 Census of agriculture - Florida state and county data: Washington D.C., U.S. Department of Agriculture, National Agricultural Statistics Service, Geographic Area Series, part 9 [AC 07-A-9], v. 1, 485 p.

U.S. Department of Agriculture, 2006, Commercial citrus inventory, preliminary report: Orlando, Fla., U.S. Department of Agriculture, National Agricultural Statistics Service, Citrus, September 15, 2006, 8 p.

U.S. Department of Agriculture, 2009, 2007 Census of agriculture-Florida state and county data: Washington D.C., U.S. Department of Agriculture, National Agricultural Statistics Service, Geographic Area Series, part 9 [AC 07-A-9], v. 1, 558 p.

U.S. Department of Agriculture, 2014, 2012 Census of agriculture-Florida state and county data: Washington D.C., U.S. Department of Agriculture, National Agricultural Statistics Service, Geographic Area Series, part 9 [AC 07-A-9], v. 1, 549 p.

White, J.K., and van Blokland, P.J., 2006, Trends in Florida citrus with emphasis on Indian River, St. Lucie, Martin, and Palm Beach Counties: Gainesville, Fla., University of Florida, Food and Resource Economics Department, EDIS FE636, 9 p.

\section{For addition information about this report, contact:}

Richard L. Marella

U.S. Geological Survey, Caribbean-Florida Water Science Center 12703 Research Parkway

Orlando, FL 32826

rmarella@usgs.gov

Or visit the Caribbean-Florida Water Science Center Web site at http://fl.water.usgs.gov
Suggested citation:

Marella, R.L., and Dixon, J.F., 2014, Agricultural irrigated land-use inventory for Osceola County, Florida, October 2013-April 2014: U.S. Geological Survey Open-File Report 2014-1257, 8 p., http://dx.doi.org/10.3133/ofr20141257. 